\title{
Influence of Semiarid Cropping Systems on Root Diseases and Inoculum Density of Soilborne Pathogens
}

Richard W. Smiley, Professor, Stephen Machado, Associate Professor, Jennifer A. Gourlie, Faculty Research Assistant, Larry C. Pritchett, Faculty Research Assistant, Guiping Yan, Research Associate, and Erling E. Jacobsen, Farm Manager, Oregon State University, Columbia Basin Agricultural Research Center, Pendleton 97801

\begin{abstract}
Smiley, R. W., Machado, S., Gourlie, J. A., Pritchett, L. C., Yan, G. P., and Jacobsen, E. E. 2013. Influence of semiarid cropping systems on root diseases and inoculum density of soilborne pathogens. Plant Dis. 97:547-555.

There is interest in converting the 2-year rotation of rainfed winter wheat with cultivated fallow in the Pacific Northwest of the United States into direct-seed (no-till) systems that include chemical fallow, spring cereals, and food-legume and brassica crops. Eight cropping systems in a low-precipitation region $(<330 \mathrm{~mm})$ were compared over 9 years to determine effects of changes on diseases. Fusarium crown rot was more prevalent in wheat following cultivated than chemical fallow, and Rhizoctonia root rot was more severe when winter wheat was rotated with chemical fallow than with no-till winter pea. Take-all occurred even during the driest years and was more severe on annual

spring wheat than on annual spring barley. Inoculum density (picograms of DNA per gram of soil) differed $(\alpha<0.05)$ among cropping systems for Fusarium culmorum, F. pseudograminearum, Gaeumannomyces graminis var. tritici, and Pythium spp. but not for Rhizoctonia solani AG-8. Phoma medicaginis var. pinodella was detected only where winter pea was planted frequently. This is the first report of $P$. medicaginis as a component of the dryland stem rot complex of pea in north-central Oregon. Results of this investigation will provide guidance for developing crop species with resistance to Fusarium crown rot and black stem of pea.
\end{abstract}

Root and crown diseases are common on field crops in the lowprecipitation region $(<300 \mathrm{~mm}$ annually) of the Pacific Northwest. Fusarium crown rot (Fusarium culmorum and F. pseudograminearum) becomes most damaging in the lowest-precipitation regions, particularly when winter wheat (Triticum aestivum L.) is sown deeply into warm soil during late summer to early autumn, which is common in cultivated fallow systems, and when wheat is sown shallowly into fields with high levels of crop residue remaining on the surface, as is common in direct-seed systems $(13,36,48$, $50,51,56)$. Rhizoctonia root rot (Rhizoctonia solani AG-8) is most prevalent in direct-seed systems and, particularly, in spring barley (Hordeum vulgare L.) and in fields that are planted annually $(14,28,31,36,58,59,60)$. Pythium diseases caused by multiple species are particularly prevalent in direct-seed systems when seed is planted into cool, wet soil $(10,15,22,36,57)$. The "dryland" form of take-all (Gaeumannomyces graminis var. tritici) occurs regularly and is most prevalent in annual crops and in direct-seed systems $(12,14,29,36,38,50)$. Root-lesion nematode (Pratylenchus neglectus and $P$. thornei) densities are strongly influenced by the frequency at which hosts are produced in the cropping system and are more prevalent in cultivated than in direct-seed systems and following wheat compared with barley $(53,54)$.

In low-precipitation regions of Oregon and Washington, food legume crops such as winter pea (Pisum sativum L. var. arvense (L.) Poir), spring pea (P. sativum L.), and chickpea (Cicer arietinum L.) are commonly affected by a root and stem rot complex that includes Fusarium root rot $(F$. solani), Rhizoctonia seedling rot (R. solani); Pythium damping-off, root rot, and root-tip necrosis (Pythium spp.); and black root rot (Thielaviopsis basicola) $(6,17,19)$. Food and forage legume crops in higher-precipitation $(>450 \mathrm{~mm})$ and irrigated areas of the Pacific Northwest are also affected by black stem rot and foot rot (Phoma medicaginis var.

Corresponding author: R. Smiley, E-mail: richard.smiley@ oregonstate.edu

Accepted for publication 15 November 2012.

http://dx.doi.org/10.1094/PDIS-09-12-0834-RE

(C) 2013 The American Phytopathological Society pinodella), Aphanomyces root rot (Aphanomyces euteiches), and Fusarium wilt (F. oxysporum) $(1,2,17,46)$. Zerlik $(62)$ reported studies on the etiology and epidemiology of a similar cortical necrosis of pea epicotyls and roots and coined the name "late yellowing and foot rot" to describe a disease caused by multiple potential pathogens.

Rainfed wheat is planted each year on 1.5 million ha in the very dry (150 to $200 \mathrm{~mm}$ of precipitation annually) and low-precipitation (200 to $300 \mathrm{~mm}$ ) regions of north-central Oregon and southcentral Washington. Precipitation occurs mostly (75\%) from late autumn (October) to early spring (April) and the amount is highly variable from year to year. Winters are cold and intervals of frozen soil are common. Warm to hot days and cool nights prevail during the dry summer period. Optimal grain yield for cereal crops is dependent upon healthy root systems capable of extracting water stored deep in the soil profile.

In all, $90 \%$ of the hectares planted in the $<330 \mathrm{~mm}$ annual precipitation area are managed as a 2-year monoculture of winter wheat (10-month growing period) "rotated" with a 14-month fallow $(43,44)$. Most fallow is managed as a mechanically cultivated "dust mulch". Direct-seeding into non-tilled chemical fallow is of strong interest in the lower-precipitation region but still is not as widely used as mechanical cultivation because direct-seed systems have historically been less profitable than mechanical fallow systems when fuel and fertilizer expenses were not excessive $(3,26,42,43)$. The cultivated and non-tilled fallow systems each favor comparatively high wheat yield because they retain as much as $30 \%$ of the precipitation occurring during the fallow winter. Therefore, each winter wheat crop has access to water equivalent to as much as $60 \%$ of precipitation occurring during the 24-month rotational sequence. Winter wheat in the lowest-precipitation areas must be fully emerged and established by late summer to early autumn to avoid an agronomic yield penalty of up to $50 \%$ associated with late-autumn plantings. Cultivated fallow systems have been designed to maintain, directly below the dust mulch, a soil moisture content that is adequate for seed germination and seedling emergence. Deep-furrow seed drills are used to plant seed into this comparatively shallow zone of soil moisture during late summer to early autumn. Although non-tilled fallow has about the same total amount of available water in the soil profile, the moisture is more 
deeply placed in the profile and cannot be accessed by seed drills. Therefore, wheat must be planted shallowly into non-tilled fallow at a time when precipitation is predicted or has begun during the autumn. The timing of the onset of autumn precipitation in the region is highly variable and often occurs when soil is far too cold for rapid seedling establishment, resulting in yield reductions that can be as high as 30 to $50 \%$, compared with yields from nearby winter wheat established earlier on cultivated fallow. This has been a strong impediment to grower acceptance of the no-till fallow system for winter wheat in low-precipitation regions of Oregon and Washington.

Three-year rotations of winter wheat, a spring crop, and chemical summer fallow are also of interest (40) but have not been widely adopted in the low-precipitation zone because they also have been less profitable and have had greater year-to-year economic risk compared with winter wheat-summer fallow rotations. Although practiced on only a small percentage of hectares, most direct-seeded annually planted fields in the low-precipitation region are planted repeatedly to spring wheat or spring barley because these crops have been more profitable than rotation with crops such as yellow mustard (Sinapsis alba L.), canola (Brassica napus L.), or camelina (Camelina sativa (L.) Crantz), albeit less profitable than winter wheat rotated with fallow $(23,41)$. Winter field pea is of interest to growers in low-precipitation regions and spring pea is commonly produced in regions where higher precipitation $(>450 \mathrm{~mm})$ is more favorable for annual cropping systems.

A replicated multiyear experiment was established during 2003 to examine multidisciplinary aspects of eight representative cropping systems at a low-precipitation site infested with most of the aforementioned pathogens. Smiley and Machado (52) previously reported an inverse relationship between density of $P$. neglectus and yield of winter wheat during the first 5 years of the experi- ment, and that winter wheat treatments most affected by the nematode also extracted the least amount of water from the soil profile. We also reported effects of tillage and crop rotations on densities of Pratylenchus spp. and of the differential effects of specific crops on individual species of Pratylenchus (53). This article reports associations between cropping systems and the incidence and severity of root and crown diseases caused by soilborne fungal pathogens over the 9-year experimental period. Diseases were monitored visually each year and, during the final year, the inoculum densities for 14 potential pathogens or pathogen groups were also estimated by real-time polymerase chain reaction on DNA extracted from soil (32).

\section{Materials and Methods}

The experiment was performed at the Columbia Basin Agricultural Research Center $1 \mathrm{~km}$ southeast of Moro, Sherman County, OR $\left(45^{\circ} 29.041^{\prime} \mathrm{N}\right.$ and $\left.120^{\circ} 43.127^{\prime} \mathrm{W}\right)$. The site is at $575 \mathrm{~m}$ of elevation and receives $282 \mathrm{~mm}$ of mean annual precipitation, nearly all of which occurs from late autumn (October) through spring (May). Mean daily air temperature is $-1^{\circ} \mathrm{C}$ during January and $19^{\circ} \mathrm{C}$ during July and August. Soil is a moderately deep (mostly $>120 \mathrm{~cm}$ ) Walla Walla silt loam; a coarse-silty, mixed, superactive, mesic Typic Haploxeroll. Daily precipitation was measured at an official U.S. National Weather Service recording site located $0.5 \mathrm{~km}$ from the experimental site.

Cropping systems. A uniform crop of spring wheat was planted over the intended experimental area during 2003. The experimental area was mapped into 42 plots of 15 by $105 \mathrm{~m}$ arranged as 14 treatments of eight crop rotations, randomized within each of three blocks. Each phase of each rotation was present each year to allow data for each treatment to be collected every year. Crops and cultivars or the type of fallow are shown in Table 1. Crops were har-

Table 1. Crop and management treatments over 9 years (2004 to 2012) in a long-term experiment at Moro, OR

\begin{tabular}{|c|c|c|c|c|c|c|c|c|c|c|c|}
\hline \multirow[b]{2}{*}{ Treatment $^{y}$} & \multirow[b]{2}{*}{$\mathbf{R} \mathbf{N}^{\mathbf{z}}$} & \multirow[b]{2}{*}{ Phase } & \multicolumn{9}{|c|}{ Crop and cultivar or fallow type during each harvest year ${ }^{x}$} \\
\hline & & & 2004 & 2005 & 2006 & 2007 & 2008 & 2009 & 2010 & 2011 & 2012 \\
\hline \multirow[t]{2}{*}{$\mathrm{WW} / \mathrm{CvF}$} & 1 & $1 \mathrm{~A}$ & $\begin{array}{l}\text { WW } \\
\text { Tubbs }\end{array}$ & $\mathrm{CvF}$ & $\begin{array}{c}\text { WW } \\
\text { Stephens }\end{array}$ & $\mathrm{CvF}$ & $\begin{array}{c}\text { WW } \\
\text { ORCF101 }\end{array}$ & $\mathrm{CvF}$ & $\begin{array}{c}\text { WW } \\
\text { ORCF102 }\end{array}$ & $\mathrm{CvF}$ & $\begin{array}{c}\text { WW } \\
\text { ORCF101 }\end{array}$ \\
\hline & & $1 \mathrm{~B}$ & $\mathrm{CvF}$ & $\begin{array}{l}\text { WW } \\
\text { Tubbs }\end{array}$ & $\mathrm{CvF}$ & $\begin{array}{c}\text { WW } \\
\text { Stephens }\end{array}$ & $\mathrm{CvF}$ & $\begin{array}{c}\text { WW } \\
\text { Tubbs`06 }\end{array}$ & $\mathrm{CvF}$ & $\begin{array}{c}\text { WW } \\
\text { ORCF101 }\end{array}$ & $\mathrm{CvF}$ \\
\hline \multirow[t]{2}{*}{ WW/ChF } & 2 & $2 \mathrm{~A}$ & $\begin{array}{l}\text { WW } \\
\text { Tubbs }\end{array}$ & $\mathrm{ChF}$ & $\begin{array}{c}\text { WW } \\
\text { Stephens }\end{array}$ & $\mathrm{ChF}$ & $\begin{array}{c}\text { WW } \\
\text { ORCF101 }\end{array}$ & $\mathrm{ChF}$ & $\begin{array}{c}\text { WW } \\
\text { ORCF102 }\end{array}$ & $\mathrm{ChF}$ & $\begin{array}{c}\text { WW } \\
\text { ORCF101 }\end{array}$ \\
\hline & & $2 \mathrm{~B}$ & $\mathrm{ChF}$ & $\begin{array}{l}\text { WW } \\
\text { Tubbs }\end{array}$ & $\mathrm{ChF}$ & $\begin{array}{c}\text { WW } \\
\text { Stephens }\end{array}$ & $\mathrm{ChF}$ & $\begin{array}{c}\text { WW } \\
\text { Tubbs`06 }\end{array}$ & $\mathrm{ChF}$ & $\begin{array}{c}\text { WW } \\
\text { ORCF101 }\end{array}$ & $\mathrm{ChF}$ \\
\hline Annual WW & 3 & 3 & $\begin{array}{l}\text { WW } \\
\text { Tubbs }\end{array}$ & $\begin{array}{l}\text { WW } \\
\text { Tubbs }\end{array}$ & $\begin{array}{c}\text { WW } \\
\text { Stephens }\end{array}$ & $\begin{array}{c}\text { WW } \\
\text { ORCF101 }\end{array}$ & $\begin{array}{c}\text { WW } \\
\text { ORCF101 }\end{array}$ & $\begin{array}{c}\text { WW } \\
\text { Tubbs'06 }\end{array}$ & $\begin{array}{c}\text { WW } \\
\text { ORCF102 }\end{array}$ & $\begin{array}{c}\text { WW } \\
\text { ORCF101 }\end{array}$ & $\begin{array}{c}\text { WW } \\
\text { ORCF101 }\end{array}$ \\
\hline Annual SW & 4 & 4 & $\begin{array}{l}\text { SW } \\
\text { Zak }\end{array}$ & $\begin{array}{l}\text { SW } \\
\text { Zak }\end{array}$ & $\begin{array}{c}\text { SW } \\
\text { Louise }\end{array}$ & $\begin{array}{c}\text { SW } \\
\text { Louise }\end{array}$ & $\begin{array}{c}\text { SW } \\
\text { Louise }\end{array}$ & $\begin{array}{c}\text { SW } \\
\text { Louise }\end{array}$ & $\begin{array}{c}\text { SW } \\
\text { Louise }\end{array}$ & $\begin{array}{c}\text { SW } \\
\text { Louise }\end{array}$ & $\begin{array}{c}\text { SW } \\
\text { Louise }\end{array}$ \\
\hline Annual SB & 5 & 5 & $\begin{array}{c}\text { SB } \\
\text { Camas }\end{array}$ & $\begin{array}{c}\text { SB } \\
\text { Camas }\end{array}$ & $\begin{array}{c}\text { SB } \\
\text { Camas }\end{array}$ & $\begin{array}{c}\text { SB } \\
\text { Camas }\end{array}$ & $\begin{array}{c}\text { SB } \\
\text { Haxby }\end{array}$ & $\begin{array}{c}\text { SB } \\
\text { Camas }\end{array}$ & $\begin{array}{c}\text { SB } \\
\text { Camas }\end{array}$ & $\begin{array}{c}\text { SB } \\
\text { Camas }\end{array}$ & $\begin{array}{c}\text { SB } \\
\text { Camas }\end{array}$ \\
\hline \multirow[t]{3}{*}{ WW/SB/ChF } & 6 & $6 \mathrm{~A}$ & $\begin{array}{c}\text { WW } \\
\text { Tubbs }\end{array}$ & $\begin{array}{c}\text { SB } \\
\text { Camas }\end{array}$ & $\mathrm{ChF}$ & $\begin{array}{c}\text { WW } \\
\text { ORCF101 }\end{array}$ & $\begin{array}{c}\text { SB } \\
\text { Haxby }\end{array}$ & $\mathrm{ChF}$ & $\begin{array}{c}\text { WW } \\
\text { ORCF102 }\end{array}$ & $\begin{array}{c}\text { SB } \\
\text { Camas }\end{array}$ & $\mathrm{ChF}$ \\
\hline & & $6 \mathrm{~B}$ & $\begin{array}{c}\text { SB } \\
\text { Camas }\end{array}$ & $\mathrm{ChF}$ & $\begin{array}{c}\text { WW } \\
\text { Stephens }\end{array}$ & $\begin{array}{c}\text { SB } \\
\text { Camas }\end{array}$ & $\mathrm{ChF}$ & $\begin{array}{c}\text { WW } \\
\text { Tubbs'06 }\end{array}$ & $\begin{array}{c}\text { SB } \\
\text { Camas }\end{array}$ & $\mathrm{ChF}$ & $\begin{array}{c}\text { WW } \\
\text { ORCF101 }\end{array}$ \\
\hline & & $6 \mathrm{C}$ & $\mathrm{ChF}$ & $\begin{array}{l}\text { WW } \\
\text { Tubbs }\end{array}$ & $\begin{array}{c}\text { SB } \\
\text { Camas }\end{array}$ & $\mathrm{ChF}$ & $\begin{array}{c}\text { WW } \\
\text { ORCF101 }\end{array}$ & $\begin{array}{c}\text { SB } \\
\text { Camas }\end{array}$ & $\mathrm{ChF}$ & $\begin{array}{c}\text { WW } \\
\text { ORCF101 }\end{array}$ & $\begin{array}{c}\text { SB } \\
\text { Camas }\end{array}$ \\
\hline \multirow[t]{2}{*}{ WW/WP } & 7 & $7 \mathrm{~A}$ & $\begin{array}{c}\text { WW } \\
\text { Tubbs }\end{array}$ & $\begin{array}{l}\text { WP } \\
706\end{array}$ & $\begin{array}{c}\text { WW } \\
\text { Stephens }\end{array}$ & $\begin{array}{c}\text { WP } \\
\text { Specter }\end{array}$ & $\begin{array}{c}\text { WW } \\
\text { ORCF101 }\end{array}$ & $\begin{array}{c}\text { WP } \\
\text { Austrian }\end{array}$ & $\begin{array}{c}\text { WW } \\
\text { ORCF102 }\end{array}$ & $\begin{array}{c}\text { WP } \\
\text { Windham }\end{array}$ & $\begin{array}{c}\text { WW } \\
\text { ORCF101 }\end{array}$ \\
\hline & & $7 B$ & $\begin{array}{c}\text { WP } \\
\text { Austrian }\end{array}$ & $\begin{array}{l}\text { WW } \\
\text { Tubbs }\end{array}$ & $\begin{array}{c}\text { WP } \\
\text { Specter }\end{array}$ & $\begin{array}{c}\text { WW } \\
\text { ORCF101 }\end{array}$ & $\begin{array}{c}\text { WP/SP } \\
\text { Universal }\end{array}$ & $\begin{array}{c}\text { WW } \\
\text { Tubbs`06 }\end{array}$ & $\begin{array}{c}\text { WP/SP } \\
\text { Universal }\end{array}$ & $\begin{array}{c}\text { WW } \\
\text { ORCF101 }\end{array}$ & $\begin{array}{c}\text { WP } \\
\text { Windham }\end{array}$ \\
\hline \multirow[t]{2}{*}{ Flex crops } & 8 & $8 \mathrm{~A}$ & $\begin{array}{c}\text { SB } \\
\text { Camas }\end{array}$ & $\begin{array}{l}\text { SW } \\
\text { Zak }\end{array}$ & $\begin{array}{c}\text { SM } \\
\text { Tilney }\end{array}$ & $\begin{array}{c}\text { SW } \\
\text { Louise }\end{array}$ & $\begin{array}{c}\text { SC } \\
\text { Calina }\end{array}$ & $\begin{array}{c}\text { SP } \\
\text { Universal }\end{array}$ & $\begin{array}{c}\text { SW } \\
\text { Louise }\end{array}$ & $\begin{array}{c}\text { SC } \\
\text { Calina }\end{array}$ & $\begin{array}{c}\text { WW } \\
\text { ORCF101 }\end{array}$ \\
\hline & & $8 B$ & $\begin{array}{l}\text { SW } \\
\text { Zak }\end{array}$ & $\begin{array}{c}\text { SB } \\
\text { Camas }\end{array}$ & $\mathrm{ChF}$ & $\begin{array}{c}\text { WW } \\
\text { ORCF101 }\end{array}$ & $\begin{array}{c}\text { SP } \\
\text { Universal }\end{array}$ & $\begin{array}{c}\text { SW } \\
\text { Louise }\end{array}$ & $\begin{array}{c}\text { SP } \\
\text { Universal }\end{array}$ & $\begin{array}{c}\text { SW } \\
\text { Louise }\end{array}$ & $\begin{array}{c}\text { SC } \\
\text { Calina }\end{array}$ \\
\hline
\end{tabular}

${ }^{\mathrm{x}} \mathrm{ChF}=$ chemical fallow, $\mathrm{CvF}=$ cultivated fallow, $\mathrm{SB}=$ spring barley, $\mathrm{SC}=$ spring camelina, $\mathrm{SM}=\mathrm{spring}$ mustard, $\mathrm{SP}=$ spring pea, $\mathrm{SW}=$ spring wheat, $\mathrm{WP}$ $=$ winter pea, $\mathrm{WW}=$ winter wheat. The experimental area was planted uniformly to spring wheat in 2003 . All rotational sequences were performed without tillage (no-till), except rotations $1 \mathrm{~A}$ and $1 \mathrm{~B}$, which were cultivated between WW crops. All WW and SW cultivars were of the soft-white winter wheat class, and all SB was two-rowed spring feed barley. Mustard 'Tilney' is a yellow (also called white) mustard (Sinapsis alba). WP/SP is winter pea that was killed during winter and replanted to spring pea.

y Treatment sequence. Flex crop = decisions regarding rotational sequences were reexamined annually to facilitate real-time considerations of available stored water, crop prices, and occurrences of weeds or diseases.

${ }^{\mathrm{z}}$ Rotation number. 
vested in late July or early August. A strip following the centerline of each $15-\mathrm{m}$ wide plot was harvested using a commercial combine with a 5.5-m header and grain yield was measured using a weigh wagon to determine yield per treatment.

Rotation 1. Two-year rotation of winter wheat and cultivated fallow. After harvest, the field was not cultivated until mid-April of the following (fallow) year. Glyphosate was applied as needed in the autumn and spring. In April, primary tillage was conducted to a depth of $15 \mathrm{~cm}$ using a John Deere 1600 cultivator fitted with chisel plow turning points, followed by sweep cultivation to a depth of $13 \mathrm{~cm}$ using the same cultivator equipped with $30-\mathrm{cm}$ wide sweeps. Plots were rod-weeded at a depth of 8 to $10 \mathrm{~cm}$ whenever necessary to control weeds. Rod-weeding is the control of weeds by pulling a longitudinal square rod that is rotating backwards below the soil surface. Plots were generally rod-weeded two or three times from May to August. In accordance with industry standards and based on soil sampling, anhydrous ammonia and gypsum were shank-applied into fallow during September to meet soil fertility requirements based upon target yields for the region. Soft-white winter wheat cultivars were planted into moist soil at 200 to 244 seeds $/ \mathrm{m}^{2}$ in mid-September using a John Deere 7616 HZ drill (Deere and Co.) with 40-cm row spacing. In-crop herbicides were applied as necessary.

Rotation 2. Two-year rotation of winter wheat and chemical fallow. Glyphosate was applied to control weeds three to four times during the chemical fallow phase. The fallowed plots were directseeded at a shallow depth and a rate of 244 seeds $/ \mathrm{m}^{2}$ using a Fabro Drill (Fabro Ltd.) during late September or early October. Seed was placed into moist or dry soil, depending upon weather conditions each year. Urea was banded $2.5 \mathrm{~cm}$ below the seed and ammonium sulfate was applied with the seed, each based upon industry standards and results of soil tests and target yields. In-crop herbicides were applied as necessary.

Rotation 3. Annual winter wheat. Plots were sprayed in late September or early October with glyphosate to control summer weeds. Plots were then direct-seeded during October or early November at a shallow depth and a rate of 220 to 240 seeds $/ \mathrm{m}^{2}$ using the Fabro disk-type drill with $30-\mathrm{cm}$ row spacing. A blend of urea and ammonium sulfate was banded $2.5 \mathrm{~cm}$ below the seed during planting and herbicides were applied to the crop in accordance with industry standards.

Rotations 4 and 5. Annual spring wheat and spring barley. Plots were sprayed with glyphosate in late September or early October. In April, the annual spring wheat and spring barley plots were direct-seeded at rates within the range of 222 to 322 seeds $/ \mathrm{m}^{2}$, depending upon anticipated moisture available each year. The Fabro drill was used to plant soft-white spring wheat and two-rowed spring feed barley cultivars. Fertilizer and herbicide applications were as described for the annual winter wheat treatment.

Rotation 6. Three-year rotation of winter wheat, spring barley, and chemical fallow. Management practices for winter wheat following chemical fallow were the same as in the 2-year direct-seed rotation, and practices for spring barley following winter wheat were the same as for the annual spring barley treatment.

Rotation 7. Two-year rotation of winter wheat and winter pea. Following winter wheat harvest, plots were sprayed with glyphosate during late September to early October. Plots were then seeded with feed-type winter field pea cultivars at 78 seeds $/ \mathrm{m}^{2}$ during October or early November using the Fabro drill. Granular inoculant was applied with the seed. Starter fertilizer ( $\mathrm{N}$ at $9 \mathrm{~kg} / \mathrm{ha}$ ) was banded below the seed, at a depth of $7.5 \mathrm{~cm}$. Herbicides were applied in accordance with standard practice. When winter pea plants succumbed to winterkill, the plots were replanted to spring field pea (Table 1). After the pea crop was harvested in late July or early August, glyphosate was applied to prepare plots for planting winter wheat. In October or early November, winter wheat was seeded at 244 seeds $/ \mathrm{m}^{2}$ using the Fabro drill. Urea was banded $2.5 \mathrm{~cm}$ below the seed during planting and starter fertilizer (ammonium sulfate) was applied with the seed. In-crop herbicides were applied as necessary.
Rotation 8. Flexible cropping sequences (Flex crop). Two directseed flexible cropping treatments (rotations $8 \mathrm{~A}$ and $8 \mathrm{~B}$ ) were examined. Each treatment allowed independent and complete annual flexibility in selecting the crop species produced, with decisions based upon market prices, soil moisture available before planting, and occurrences of weeds and diseases. Cropping decisions were made by consensus of the project leader and the scientists and farmers who served on an advisory committee for this experiment. Crops grown in these rotations (Table 1) were winter wheat or spring-planted wheat, barley, yellow mustard, canola, or camelina. Management was as described for direct-seed annual crops.

Plant diseases. Plants with intact root systems were dug to a 10$\mathrm{cm}$ depth from at least six locations in each plot when the first stem node of cereal crops was visible: between Feekes growth stages 5 and 6, during May for winter crops and mid-June for spring-planted crops. Roots were rinsed to remove adhering soil, and 20 plants from each plot were randomly selected and evaluated visually for incidence or severity of disease symptoms on roots, subcrown internodes, crowns, and culm bases. A single individual evaluated plants for disease identification and severity ratings during the first 2 and last 5 years, and trained the individual who rated diseases during the intervening 2 years. Diseases of small grains detected in this study were Fusarium crown rot, Rhizoctonia root rot, and take-all. Pathogens associated with the visual symptoms had been identified by traditional clinical procedures during the course of previous studies $(56,61)$.

Fusarium crown rot incidence was quantified as percentage of plants with subcrown internodes affected by characteristic dark lesions and also as percentage of plants with a brown dry rot of crown tissue as revealed when crowns were cut open. Severity of crown rot was assigned as follows: $0=$ no lesion on the subcrown internode, $1=1$ to $25 \%$ of area affected by lesions, $2=26$ to $50 \%$ lesion area, $3=51$ to $75 \%$ lesion area, and $4=>75 \%$ lesion area.

Rhizoctonia root rot incidence was evaluated as percentage of plants on which the seminal or the coronal root axes exhibited a brown cortical rot or the "spear tip" severance symptom. Rhizoctonia root rot severity was assessed separately on seminal and coronal roots by a scale ( 0 to 5 ) indicating relative severity of root rot symptoms, where $0=$ none and $5=$ extensive root rot on most or all roots.

The incidence of take-all was rated as the percentage of plants on which seminal roots exhibited a characteristic blackening of the root cortex or vascular system. Take-all severity was rated using a 0 -to- 5 scale, where $0=$ none and $5=$ extensive blackening on most or all roots.

Percentages of plants that exhibited a pruning of secondary or tertiary root axes were also recorded. Plants were considered to exhibit root pruning if there was evidence that branches from a primary or secondary root had been present but were now absent without evidence that they had been stripped off during handling, and had no resemblance to the spear tip termination symptom ascribed to Rhizoctonia root rot. Root pruning was typically exhibited as bluntly terminated branches, sometimes called "root nubbing". Given the presence of at least three pathogens (Pratylenchus, Pythium, and Rhizoctonia spp.) capable of causing the root pruning, no attempt was made to routinely identify specific causal agents or the relative importance of each member of the "root pruning" pathogen complex.

Pathogen identification and inoculum density. Soil samples were collected from each plot on 10 May 2012, as described for assessing nematodes in this experiment (53). About 40 soil cores ( $2.5 \mathrm{~cm}$ in diameter by $30 \mathrm{~cm}$ deep) were composited for each of the 42 plots. Samples were stored at $4^{\circ} \mathrm{C}$ for 2 days at field moisture level. A subsample was then dried in an oven at $40^{\circ} \mathrm{C}$ for $48 \mathrm{~h}$ and $500 \mathrm{~g}$ of dry soil for each plot was sent to the Root Disease Testing Service, South Australia Research and Development Institute, Adelaide, Australia. The lab extracted DNA from the entire 500-g of soil using the PreDicta B real-time PCR analysis system (32; http://www.sardi.sa.gov.au/products_and_services/entomol 
ogy/diagnostic_service/predicta_b). Previous applications of the PreDicta B analysis system for detecting inoculum densities of pathogens in soil outside of Australia have been reported by Bithell et al. (4) and Paulitz et al. (35). Inoculum concentrations in picograms of DNA per gram of soil were reported for the fungi Bipolaris sorokiniana, F. culmorum, F. pseudograminearum, G. graminis var. avenae, G. graminis var. tritici, P. koolunga, $P$. medicaginis var. pinodella, Pythium sp. clade F (25), and $R$. solani AG-8. Nematodes per gram of soil were also reported for Ditylenchus dipsaci, Heterodera avenae, Pratylenchus neglectus, $P$. thornei, and P. teres and are reported by Smiley et al. (53).

Statistical analysis. Long-term effects of rotations were evaluated by grouping disease incidence data over years for analysis using two-way analysis of variance (ANOVA), with years and rotation treatments or crops as variables and replicates as blocks. ANOVA was performed using CoStat Statistical Software (Co-Stat v. 6.400; CoHort Software). When treatment means were significant at $\alpha<0.05$, means were separated using the Tukey's honestly significant difference test if numbers of observations were uniform among treatments and by the least significant difference test when numbers of observations differed among treatments. Long-term effects of rotations on ordinate data for disease severity ratings were analyzed by the Kruskal-Wallis Test. When the $\chi^{2}$ value for the experiment was significant at $\alpha<0.05$, treatments were examined pairwise to determine which treatments differed significantly.

\section{Results}

Annual precipitation over the 9-year experimental period averaged $289 \mathrm{~mm}$ and ranged from $181 \mathrm{~mm}$ in 2008 to $396 \mathrm{~mm}$ in 2010. Precipitation during the 5-month over-winter and earlyspring period (November to March) averaged $112 \mathrm{~mm}$ over the 9year period, including two particularly dry periods $(83 \mathrm{~mm}$ in 2007 and $59 \mathrm{~mm}$ in 2008) and three comparatively wet periods (125, 171 , and $132 \mathrm{~mm}$ in 2004, 2010, and 2012, respectively).

Small grains. Visually detectable diseases of small grains included Fusarium crown rot, Rhizoctonia root rot, and take-all. Treatment effects were more effectively differentiated by disease symptoms on subcrown internodes and on seminal roots than on coronal roots (data not shown). The main effect for year was always highly significant $(\alpha<0.01)$ for diseases in crowns, subcrown internodes, and seminal roots (data not shown).
Fusarium crown rot. On winter wheat, crown rot symptoms on subcrown internodes were most prevalent and most severe in the winter wheat/cultivated fallow rotation and were least apparent in the winter wheat/winter pea rotation, the 3-year rotation, and annual winter wheat (Table 2). Rotting of internal crown tissue occurred on a low percentage of plants and was marginally significant $(\alpha=0.08)$ for the effect of rotation (data not shown). Percentages of rotted crowns were greatest in the winter wheat/conventional fallow rotation ( $2.6 \%$ of plants) and in annual winter wheat $(2.4 \%)$, intermediate in the winter wheat/chemical fallow rotation $(1.5 \%)$, and least in the wheat/pea rotation $(0.8 \%)$ and in the 3-year rotation $(0.4 \%)$.

On spring cereals, the greatest incidence and severity of crown rot occurred during 2008, the year with the least amount of overwinter and early-spring precipitation (data not shown). The incidence of crown rot, observed as lesions on subcrown internodes, was significantly $(\alpha<0.01)$ greater on annual spring barley than on annual spring wheat, with spring barley in the 3-year rotation being intermediate (Table 2). The lowest incidence of crown rot on spring cereals occurred in the more-diverse flexible cropping system. Rotting of internal crown tissue differed $(\alpha<0.01)$ for the main effect of year but did not differ significantly for main effects of rotation or crop species. Rotting of crown tissue generally was not observed on spring cereals but was present during the driest year (2008) in annual spring wheat (3\% of plants), annual spring barley (7\%), and spring barley in the 3-year rotation (10\%).

DNA analysis revealed the presence of both $F$. culmorum and $F$. pseudograminearum (Table 3). F. culmorum was detected at a high level in chemical fallow following winter wheat (rotation $2 \mathrm{~B}$ ), winter wheat following chemical fallow (rotation 6A), annual spring barley (rotation 5), spring barley following winter wheat (rotation 6B), and camelina recently planted into soil previously cropped to spring wheat (rotation $8 \mathrm{~B}$ ). The greatest DNA concentration of $F$. pseudograminearum occurred in treatments where winter wheat was rotated with cultivated or chemical fallow (rotations $1 \mathrm{~A}, 1 \mathrm{~B}, 2 \mathrm{~A}$, and 2B), in annual spring barley (rotation 5), in spring barley following winter wheat (rotation 6B), and in winter wheat following spring barley (rotation 6A). Detection of both pathogens was high in treatments that included spring barley (rotations 5 and $6 \mathrm{~B}$ ) and in the fallow phase of the winter wheat/ chemical fallow treatment. It was also of interest that detection of

Table 2. Principal root and crown diseases of winter wheat, spring wheat, and spring barley averaged over 9 years (2004 to 2012) in eight rotations of the long-term cropping systems experiment at Moro, $\mathrm{OR}^{\mathrm{y}}$

\begin{tabular}{|c|c|c|c|c|c|c|c|}
\hline \multirow[b]{2}{*}{$\mathrm{RN}$, treatment ${ }^{\mathrm{z}}$} & \multicolumn{2}{|c|}{ Fusarium crown rot } & \multicolumn{2}{|c|}{ Rhizoctonia root rot } & \multicolumn{2}{|c|}{ Take-all } & \multirow{2}{*}{$\frac{\text { Root pruning }}{\text { Inc }}$} \\
\hline & Sev & Inc & Sev & Inc & Sev & Inc & \\
\hline \multicolumn{8}{|l|}{ Winter wheat } \\
\hline 3, Annual WW & $1.6 \mathrm{~b}$ & $33 \mathrm{bc}$ & $1.0 \mathrm{ab}$ & $38 \mathrm{abc}$ & 0.8 & 8 & 11 \\
\hline $1, \mathrm{WW} / \mathrm{CvF}$ & $2.5 \mathrm{a}$ & $57 \mathrm{a}$ & $0.9 \mathrm{bc}$ & $37 \mathrm{bc}$ & 0.9 & 14 & 7 \\
\hline $2, \mathrm{WW} / \mathrm{ChF}$ & $1.9 \mathrm{ab}$ & $41 \mathrm{~b}$ & $1.2 \mathrm{a}$ & $47 \mathrm{a}$ & 0.8 & 16 & 15 \\
\hline 7, WW/WP & $1.5 \mathrm{~b}$ & $21 \mathrm{c}$ & $0.7 \mathrm{c}$ & $35 \mathrm{c}$ & 1.0 & 14 & 10 \\
\hline 6, WW/SB/ChF (WW only) & $1.5 \mathrm{~b}$ & $30 \mathrm{~cd}$ & $1.1 \mathrm{bc}$ & $46 \mathrm{ab}$ & 0.8 & 16 & 12 \\
\hline$P>F$ & $<0.01$ & $<0.01$ & $<0.01$ & $<0.01$ & 0.79 & 0.19 & 0.07 \\
\hline \multicolumn{8}{|l|}{ Spring cereals } \\
\hline 4, Annual SW & 0.9 & $14 \mathrm{bc}$ & $1.4 \mathrm{~b}$ & 56 & 0.8 & $17 \mathrm{a}$ & 2 \\
\hline 5, Annual SB & 1.2 & $28 \mathrm{a}$ & $1.9 \mathrm{a}$ & 66 & 0.5 & $9 \mathrm{bc}$ & 4 \\
\hline 6, WW/SB/ChF (SB only) & 0.9 & $23 \mathrm{ab}$ & $2.0 \mathrm{a}$ & 65 & 0.8 & $13 \mathrm{ab}$ & 7 \\
\hline 8, Flex crop $(\mathrm{SB} \& \mathrm{SW})$ & 0.6 & $4 c$ & $1.6 \mathrm{ab}$ & 53 & 0.5 & $4 c$ & 6 \\
\hline$P>F$ & 0.12 & $<0.01$ & 0.04 & 0.38 & 0.17 & 0.02 & 0.23 \\
\hline
\end{tabular}

${ }^{y}$ Severity (Sev) and incidence (Inc) ratings for diseases caused by Fusarium culmorum or F. pseudograminearum, Rhizoctonia solani AG-8, and Gaeumannomyces graminis var. tritici. $\mathrm{Sev}=$ scale of 0 to 4 for Fusarium crown rot and 0 to 5 for Rhizoctonia root rot and take-all. Inc $=$ percentages of symptomatic plants. Ratings for Fusarium crown rot are for lesions on subcrown internodes. Ratings for Rhizoctonia root rot and take-all are for disease symptoms on seminal roots. Root pruning is the incidence of plants with evidence of terminated secondary and tertiary roots due to likely individual or combined effects of species of Pythium, Rhizoctonia, and Pratylenchus. All data are the means of 20 plants evaluated for each of the 27 or 24 observations (n). Numbers followed by the same letter within a column of the winter wheat treatments are not significantly different at $\alpha=0.05$ according to the Tukey's honestly significant difference test for disease incidence and the Kruskal-Wallis test for means of ordinate disease severity ratings. For spring cereals, the least significant difference test for unequal number of replicates was used to analyze disease incidence data.

${ }^{\mathrm{z}}$ Rotation number $(\mathrm{RN})$ and treatment name or sequence. Rotations are described in Table $1 . \mathrm{ChF}=$ chemical fallow, $\mathrm{CvF}=$ cultivated fallow, $\mathrm{SB}=\mathrm{spring}$ barley, SW = spring wheat, $\mathrm{WP}=$ winter pea, and WW = winter wheat. Flex crop = variable crop sequences over years, including both SB and SW for the data in this table. Over the 9-year period, the data are means of 27 replicates of each treatment $(n=27)$, except for 24 replicates of spring cereals in the flex crop treatment. 
DNA of both Fusarium spp. was higher in annual spring barley (rotation 5) compared with annual winter wheat (rotation 3), and that the difference was statistically significant for F. culmorum. The common root rot pathogen B. sorokiniana was detected only in the annual spring barley treatment and only in a minimal inoculum density.

Rhizoctonia root rot. Distinct and well delineated patches of stunted plants, characteristic of the bare patch phase of Rhizoctonia root rot, were not observed during any year of the experiment. However, when plant height and shoot weight were measured for all plants sampled during the last 3 years of the study, we found plant height to be particularly variable in annual winter wheat, winter wheat/winter pea, and annual spring wheat, compared with other treatments (data not presented). In the named rotations, the standard errors for mean plant height were generally twice those of plant heights in other treatments.

On winter wheat, Rhizoctonia root rot was most prevalent and most severe in the winter wheat/chemical fallow and the 3-year rotations and least prevalent and least severe in the winter wheat/winter pea rotation (Table 2). DNA extractions indicated that inoculum of $R$. solani AG- 8 was present at high levels in the majority of the 14 treatments (Table 3). Although not statistically significant, the amount of inoculum detected in the fallow phase of the winter wheat/fallow rotation was lower in the cultivated fallow than in the chemical fallow. Although visual root rot symptoms were evident in most treatments where detectable DNA concentrations were high, it was also apparent that our visual assessments of low root rot incidence and severity in the winter wheat/winter pea rotation did not coincide with the high levels of DNA detected in that treatment. On crown roots of winter wheat, when averaged over years and rotational phases, the incidence but not severity of Rhizoctonia root rot differed among rotations (data not presented). On crown roots, disease severity and disease incidence rankings among rotations were identical to those discussed for seminal roots.

On spring cereals, the incidence of Rhizoctonia root rot was uniform among crop rotations but severity was greater for spring barley than for spring wheat (Table 2). The lowest severity and incidence of Rhizoctonia root rot occurred during 2008, the year with the least amount of over-winter and early-spring precipitation (data not shown). Detection of DNA of the pathogen was high in all treatments that included direct-seeded spring cereals (Table 3 ).
Take-all. Symptoms of take-all on winter wheat did not differ significantly among rotations (Table 2), and detection of DNA of G. graminis var. tritici was low throughout the trial area (Table 3). The incidence of take-all was greater on seminal roots of annual spring wheat than on annual spring barley, and was least in the flexible crop rotation (Table 2). However, the main effect of crop indicated no significant differences $(\alpha=0.76)$ among take-all incidence or severity for these two spring cereals when analyzed over years and rotations. The greatest incidence and severity of take-all occurred during 2008, the year with the least amount of over-winter and early-spring precipitation (data not shown).

Root pruning. Root pruning on winter wheat differed significantly over years $(\alpha<0.01)$, and the effect of crop rotation was marginally significant at $\alpha=0.07$. The year-rotation interaction was not significant $(\alpha<0.43)$. Root pruning was greatest in directdrill rotations with the greatest amount of surface residue between and within crops, and least in the rotation of winter wheat with cultivated fallow (Table 2). The incidence of root pruning of winter wheat was unrelated to annual precipitation variables. Detection of DNA from the most likely pathogens was high in most of these treatments: Pythium and Rhizoctonia spp. (Table 3) and Pratylenchus spp. (53). The incidence of root pruning did not differ among treatments of spring cereals (Table 2) and the effect of year (e.g., precipitation) and the year-treatment interaction were each insignificant.

Food legume crops. Winter pea was produced in an annual rotation with winter wheat in rotation 7 (Table 1), except when the crop failed due to winterkill in rotation 7B during crop years 2008 and 2010. Darkened lesions occurred on cotyledons and on upper taproots of winter pea each year. No attempt was made to distinguish lesion type or the causal pathogen through traditional culturing procedures. Primary pathogens revealed by DNA analysis in rotation 7 during 2012 included $R$. solani AG-8, Pythium spp., and Phoma medicaginis var. pinodella (Table 3), each of which was more prevalent in the rotation phase currently planted to winter pea (rotation 7B; Table 1) than in the rotation phase currently planted to winter wheat (rotation 7A). The difference in quantity of DNA for each pathogen in these rotations was significant $(\alpha<0.05)$ for Pythium spp. and $P$. medicaginis but not for $R$. solani. Disease severity ratings on both cotyledons and roots were always 2.0 or less on the 0 -to- 4 rating scale and did not differ significantly $(\alpha>$ 0.62 ) across years or rotation phase (data not shown). In contrast,

Table 3. DNA concentrations of soilborne plant-pathogenic fungi in 14 treatments of eight cropping systems at Moro, OR.

\begin{tabular}{|c|c|c|c|c|c|c|c|c|c|c|}
\hline \multirow[b]{2}{*}{$\underline{\mathbf{R P y}}$} & \multirow[b]{2}{*}{ Treatment $^{\mathbf{z}}$} & \multicolumn{2}{|c|}{ Crop or treatment ${ }^{w}$} & \multicolumn{7}{|c|}{ Picograms of fungal pathogen DNA per gram of soil ${ }^{x}$} \\
\hline & & Current & Previous & Ggt & Rs & Fps & Fc & Bs & Pyth & Pmp \\
\hline $1 \mathrm{~A}$ & $\mathrm{WW} / \mathrm{CvF}$ & WW & $\mathrm{CvF}$ & $0 \pm 0$ & $14 \pm 11$ & $23 \pm 10 a b c$ & $4 \pm 1 b c$ & $0 \pm 0 \mathrm{~b}$ & $71 \pm 13 \mathrm{~cd}$ & $0 \pm 0 \mathrm{~b}$ \\
\hline 1B & $\mathrm{WW} / \mathrm{CvF}$ & $\mathrm{CvF}$ & WW & $1 \pm 1$ & $6 \pm 4$ & $19 \pm 9 a b c$ & $6 \pm 2 b c$ & $0 \pm 0 b$ & $74 \pm 29 \mathrm{~cd}$ & $0 \pm 0 \mathrm{~b}$ \\
\hline $2 \mathrm{~A}$ & $\mathrm{WW} / \mathrm{ChF}$ & WW & $\mathrm{ChF}$ & $1 \pm 0$ & $10 \pm 7$ & $29 \pm 28 \mathrm{ab}$ & $2 \pm 1 \mathrm{bc}$ & $0 \pm 0 \mathrm{~b}$ & $83 \pm 21 \mathrm{~cd}$ & $0 \pm 0 \mathrm{~b}$ \\
\hline $2 \mathrm{~B}$ & $\mathrm{WW} / \mathrm{ChF}$ & $\mathrm{ChF}$ & WW & $0 \pm 0$ & $19 \pm 7$ & $33 \pm 20 a$ & $26 \pm 24 a b c$ & $0 \pm 0 \mathrm{~b}$ & $31 \pm 2 d$ & $0 \pm 0 \mathrm{~b}$ \\
\hline 3 & Annual WW & WW & WW & $0 \pm 0$ & $13 \pm 9$ & $5 \pm 4 \mathrm{bc}$ & $1 \pm 1 \mathrm{c}$ & $0 \pm 0 \mathrm{~b}$ & $70 \pm 6 \mathrm{~cd}$ & $0 \pm 0 \mathrm{~b}$ \\
\hline 4 & Annual SW & SW & SW & $1 \pm 0$ & $49 \pm 12$ & $4 \pm 1 \mathrm{bc}$ & $7 \pm 3 b c$ & $0 \pm 0 \mathrm{~b}$ & $145 \pm 36 \mathrm{~cd}$ & $0 \pm 0 \mathrm{~b}$ \\
\hline 5 & Annual SB & SB & SB & $1 \pm 0$ & $35 \pm 10$ & $25 \pm 12 a b c$ & $28 \pm 15 a b$ & $1 \pm 1 \mathrm{a}$ & $115 \pm 33 \mathrm{~cd}$ & $0 \pm 0 \mathrm{~b}$ \\
\hline $6 \mathrm{~A}$ & $\mathrm{WW} / \mathrm{SB} / \mathrm{ChF}$ & WW & $\mathrm{ChF}$ & $1 \pm 0$ & $31 \pm 29$ & $4 \pm 2 b c$ & $79 \pm 15 \mathrm{a}$ & $0 \pm 0 \mathrm{~b}$ & $40 \pm 3 \mathrm{~d}$ & $0 \pm 0 \mathrm{~b}$ \\
\hline $6 \mathrm{~B}$ & $\mathrm{WW} / \mathrm{SB} / \mathrm{ChF}$ & SB & WW & $1 \pm 0$ & $43 \pm 30$ & $13 \pm 5 a b c$ & $18 \pm 14 \mathrm{abc}$ & $0 \pm 0 \mathrm{~b}$ & $93 \pm 24 \mathrm{~cd}$ & $0 \pm 0 \mathrm{~b}$ \\
\hline $6 \mathrm{C}$ & $\mathrm{WW} / \mathrm{SB} / \mathrm{ChF}$ & $\mathrm{ChF}$ & SB & $0 \pm 0$ & $37 \pm 28$ & $4 \pm 2 b c$ & $3 \pm 2 b c$ & $0 \pm 0 \mathrm{~b}$ & $173 \pm 73 \mathrm{bc}$ & $0 \pm 0 \mathrm{~b}$ \\
\hline $7 \mathrm{~A}$ & WW/WP & WW & WP & $1 \pm 0$ & $29 \pm 5$ & $1 \pm 1 \mathrm{c}$ & $9 \pm 5 b c$ & $0 \pm 0 \mathrm{~b}$ & $82 \pm 8 \mathrm{~cd}$ & $76 \pm 34 a$ \\
\hline $7 \mathrm{~B}$ & WW/WP & WP & WW & $1 \pm 0$ & $48 \pm 32$ & $3 \pm 1 b c$ & $3 \pm 0 \mathrm{bc}$ & $0 \pm 0 \mathrm{~b}$ & $445 \pm 117 \mathrm{a}$ & $114 \pm 28 \mathrm{a}$ \\
\hline $8 \mathrm{~A}$ & Flex crop & WW & Cam & $1 \pm 0$ & $22 \pm 7$ & $1 \pm 1 c$ & $1 \pm 1 \mathrm{c}$ & $0 \pm 0 \mathrm{~b}$ & $386 \pm 53 \mathrm{ab}$ & $0 \pm 0 \mathrm{~b}$ \\
\hline \multirow[t]{2}{*}{$8 \mathrm{~B}$} & Flex crop & Cam & SW & $1 \pm 0$ & $30 \pm 24$ & $5 \pm 3 b c$ & $15 \pm 12 a b c$ & $0 \pm 0 \mathrm{~b}$ & $143 \pm 18 \mathrm{~cd}$ & $0 \pm 0 \mathrm{~b}$ \\
\hline & $P>F$ & $\ldots$ & $\ldots$ & 0.06 & 0.60 & 0.02 & $<0.01$ & $<0.01$ & $<0.01$ & $<0.01$ \\
\hline
\end{tabular}

${ }^{\mathrm{w}}$ Crops and management treatments are shown in Table $1 . \mathrm{Cam}=$ camelina, $\mathrm{ChF}=$ chemical fallow, $\mathrm{CvF}=$ cultivated fallow, $\mathrm{SB}=$ spring barley, $\mathrm{SW}=$ spring wheat, $\mathrm{WP}=$ winter pea, $\mathrm{WW}=$ winter wheat, Flex crop = variable crop sequences over years. These data are for soil collected from each treatment during May 2012.

${ }^{x}$ Quantity of fungal DNA reported by the Root Disease Testing Service (Adelaide, Australia); mean and standard error of the mean for three replicates of each rotation phase. Pathogens included Gaeumannomyces graminis var. tritici (Ggt), Rhizoctonia solani AG-8 (Rs), Fusarium pseudograminearum (Fps), Fusarium culmorum $(\mathrm{Fc})$, Bipolaris sorokiniana $(\mathrm{Bs})$, Pythium sp. Clade F (Pyth), and Phoma medicaginis var. pinodella (Pmp). Numbers followed by the same letter within a column and within a group are not significantly different at $\alpha=0.05$ according to the Tukey's honestly significant difference test.

${ }^{y}$ Rotation phase.

z Treatment name or sequence. 
disease incidence differed significantly $(\alpha<0.01)$ across years for symptoms on both cotyledons and roots. Disease incidence on cotyledons varied from 5\% in 2006 to $88 \%$ in the year (2008) having the least spring-time precipitation. Likewise, disease incidence on roots varied from $3 \%$ in 2007 to $100 \%$ in 2008. During 2008, the year with the driest spring, we also detected a reduction in branching of secondary and tertiary roots on $65 \%$ of plants. This root-pruning symptom was not detected during other years.

Spring pea was produced during 3 years in rotation 8 (Table 1 , Flexible crop decisions): in rotation 8A during 2009 and in rotation $8 \mathrm{~B}$ in 2008 and 2010 . Total disease incidence ( $>60 \%$ of plants) and severity ratings ( 1.5 or less) did not differ among years $(\alpha>0.39)$. Detection of DNA for pathogens capable of causing symptoms on spring pea (Table 3) included $R$. solani AG-8 and Pythium spp. We did not detect DNA of $P$. medicaginis var. pinodella in either phase of the flex-crop rotation during 2012. As with winter pea, during 2008 , we detected a reduction in branching of secondary and tertiary roots on $53 \%$ of plants, and this root-pruning symptom was not detected during other years.

Diseases of brassica crops. No diseases were detected on roots or stems of mustard, which was produced only during 2006 in rotation 8A (Table 1). Camelina was produced in rotation 8A during 2008 and 2011 and in rotation 8B during 2012. Lesions on the lower stem were present each year and were very prevalent $(70 \%$ of plants) during the driest year (2008) and barely detectable $(<2 \%$ of plants) in 2011 and 2012. However, even in 2008, the lesion severity rating was low (1.2 on a 0 -to-4 scale). Similar observations occurred for the incidence of lesions on roots: $82 \%$, none, and $12 \%$ during 2008, 2011, and 2012, respectively. The severity of root lesion symptoms was minor: 1.3 during 2008 and 0.7 during 2012. During 2008, we also detected a reduction in branching of secondary and tertiary roots on $49 \%$ of plants. This root-pruning symptom was not detected during 2011 and 2012. Detection of DNA for pathogens capable of causing symptoms on brassica crops (Table 3) included $R$. solani AG-8, Pythium spp., and Pratylenchus spp. (53).

\section{Discussion}

Root diseases were evaluated over 9 years in a long-term cropping systems experiment in a semiarid region of Oregon, where root and crown diseases are far more prevalent than diseases of foliage or inflorescens. Diseases of wheat and barley included Fusarium crown rot, Rhizoctonia root rot, Pythium root rot, and "dryland take-all". Root-lesion nematodes were also important components of the pathogen complex and were reported separately $(52,53)$. Diseases of food legume and brassica crops were monitored annually for incidence and severity of specific types of disease symptoms but identification of specific diseases using clinical procedures was not attempted. Subsequent analysis of DNA implicated species of Pythium, Rhizoctonia, Phoma, and Pratylenchus as the most likely pathogens.

Soilborne fungi that cause the root and crown diseases survive either in a dormant state in soil or in root, crown, or basal stem tissues of plants that were infected while living $(5,11,24,27,39)$. Pathogen inoculum declines over time as dormancy structures are subjected to multiple wetting and drying cycles that stimulate activity of the soil microbiota and reduce the mass of residue available for harboring pathogen inoculum (7). In the region of this study, most precipitation occurs when soils are too cold for an abundance of microbial activity. When soils are warm, it is also generally too dry for optimal microbial activity. Decomposition of residue (and pathogen inoculum) is thought to occur at a minimal level for as many as 8 months of the year because the soil or soilsurface environments are either too dry or too cold for active microbial decomposition during summers and winters. As such, crop residue and inoculum in this environment persists for long periods, particularly when the residue remains on or near the soil surface in direct-seed cropping systems $(7,18)$. Likewise, in cultivated fallow, the surface 10 to $15 \mathrm{~cm}$ is allowed to become air dry to break the continuity of capillary flow and thereby protect from evaporative loss the water in the underlying soil. The lack of effective rotational diversity or rotation length provides an opportunity for efficient survival of pathogen inoculum from one crop to the next. In our study, the persistence of pathogen inoculum even during long periods of fallow was revealed through DNA analyses. In particular, inoculum levels were elevated during fallow periods for $R$. solani AG- $8, F$. culmorum, F. pseudograminearum, and species of Pythium.

As reported by Schroeder and Paulitz (45), we found Fusarium crown rot to be more severe and more prevalent when winter wheat was planted into cultivated fallow than into chemical fallow. We previously reported a strong relationship between the date of planting and the occurrence of Fusarium crown rot (48). In accordance with long-standing practices in the area (42), winter wheat was planted as much as 4 weeks earlier into cultivated fallow than into chemical fallow. Moreover, when wheat is planted into cultivated fallow, it is planted into warm, moist soil beneath a surface dust mulch that preserves moisture at a deeper depth. In contrast, wheat planted into chemical fallow is either placed shallowly into dry soil in anticipation of the onset of autumn precipitation or is placed shallowly into moist soil following the onset of autumn precipitation or while soil is still moist during the spring. The Fusarium spp. that cause crown rot can infect any tissue but often invade the coleoptile as it emerges (becoming the subcrown internode), or may invade the crown tissue as the outer leaf sheath tissue is ruptured during emergence of coronal roots $(8,13,49)$. Therefore, compared with direct-seed cropping systems in the region, winter wheat planted into cultivated fallow is typically planted into soil environments that are more favorable for invasion by Fusarium spp.

During 2012, we found that the concentration of DNA of $F$. pseudograminearum was generally higher than that of $F$. culmorum in winter wheat/fallow rotations and was more equivalent for the two pathogens in treatments that included spring barley. Soils for this analysis were collected in the spring before the soil in the cultivated fallow sequence had been cultivated. Samples from the current wheat crops were collected within the row and samples from fallow were centered on the rows of wheat residue remaining from the previous crop. Although these DNA data were limited to 1 year, our results suggest that the greater DNA concentrations in the spring barley treatments coincide with a higher mean severity and incidence of Fusarium crown rot in spring barley than in spring wheat. It was also suggested from the DNA analysis that $F$. $c u l$ morum and $F$. pseudograminearum were nearly equally present in spring barley, and that inoculum density of $F$. pseudograminearum was greater than that of $F$. culmorum in most winter wheat and spring wheat treatments. Although barely detectable, it was notable that $B$. sorokiniana was found only in the annual spring barley treatment. This common root rot pathogen is typically considered to be a minor component of the "dryland foot rot" complex that is dominated by Fusarium crown rot in this region (56).

Rhizoctonia root rot of small grain cereals is well defined in low-precipitation regions of the Pacific Northwest. The disease is generally more damaging to spring barley than to spring or winter wheat, and is generally more damaging in annual crops in directseed than cultivated cropping systems $(14,28,31,36,48)$. Our results are in agreement with these previous investigations and reviews. We also found that Rhizoctonia root rot was more prevalent and more severe when winter wheat was rotated with chemical fallow than cultivated fallow. Moreover, when winter wheat was grown in a 2-year direct-seed system, Rhizoctonia root rot was less prevalent and less severe when the wheat was rotated with winter pea than with chemical fallow, even though winter pea is a known suscept for this disease. This relationship was similar to a finding we previously reported for rotations in a 414-mm precipitation area of Oregon, where the incidence and severity of Rhizoctonia root rot were each significantly inversely correlated with microbial biomass (50). With respect to incidence and severity of Rhizoctonia root rot, winter wheat in the 2-year rotation with chemical fallow did not differ significantly from the annual winter wheat 
treatment. Nevertheless, DNA evidence provided support for the hypothesis that inoculum density of $R$. solani AG- 8 declines during the fallow phase of rotations in the semiarid region where this experiment was performed. It was notable, however, that DNA profiles of this pathogen indicated that it was present in amplified inoculum densities in most of the rotations. Therefore, these results are similar to those reported for cropping systems in the same environment when long-term rainfed wheat land is converted into an irrigated wheat production system (35) and when the winter wheat/fallow rotation is converted from a cultivated to a direct-seed system (45). Although the DNA analysis for determining inoculum density in our study was specific to $R$. solani AG-8 (32), it is well recognized that $R$. oryzae is also a very common component of the Rhizoctonia disease complex for wheat in the Pacific Northwest $(30,31,34,45,59)$.

Classical take-all symptoms include a blackening of roots, crown, and lower stem $(14,29,38)$. The classical symptom occurs in regions of high precipitation, particularly during the mid- to late-growing season, or in irrigated cereals. In low-precipitation dryland regions, take-all symptoms are restricted to the seminal roots and, while restricting water uptake particularly from deepfeeding seminal roots, the plants are not noticeably stunted and it is difficult to demonstrate a reduction in grain yield or grain quality. In this study, dryland take-all occurred even during the driest of the 9 years, during 2008, and was more severe on annual spring wheat than on annual spring barley. Cook (12) reviewed literature relating to enhanced survival of $G$. graminis var. tritici in dry soils compared with warm, moist soils. In this study, we demonstrated the chronic occurrence of dryland take-all and the presence of a very low level of inoculum occurring in most of the rotational treatments. Concentrations of DNA of less than $5 \mathrm{pg} / \mathrm{g}$ of soil are considered "below detectable limits" for G. graminis var. tritici when using the PreDicta B diagnostic service (4). Therefore, inoculum concentrations were too low to identify differences among treatments of this experiment. Nevertheless, when land first becomes irrigated after being in a rainfed, low-precipitation environment where wheat has been produced for many decades, inoculum density of G. graminis var. tritici quickly becomes elevated and causes classical take-all symptoms when wheat is produced (35). It is also of interest to examine the dryland take-all symptom in greater detail because it may be possible to confuse blackened root segments caused by take-all and by root-lesion nematodes. It appears coincidental, in retrospect, that the greatest dryland takeall occurred during 2008, coinciding with the year in which the greatest density of Pratylenchus spp. was measured (53). We also noted in 2008 that the dryland take-all incidence and severity ratings were greater for spring wheat than for spring barley, which lends further emphasis to the need to determine whether at least some of the visual ratings of "dryland take-all" during dry years might actually be a symptom caused by root-lesion nematodes.

Diseases caused by species of Pythium are well known in the low-precipitation regions $(10,15,16)$ but the absence of visually diagnostic symptoms makes it difficult to evaluate differences among treatments without the use of laborious and expensive clinical procedures that were beyond the scope and capability of our investigation. Nevertheless, it has been well established that all seed treatments sold in the Pacific Northwest must contain a fungicide component capable of suppressing seed rot and seedling damping-off by Pythium spp. (57). Multiple species of Pythium are complicit in causing diseases of seed, seedlings, and more mature plants $(21,33,44)$. In this study, we did not attempt to specifically identify diseases caused by Pythium spp. but it was assumed that these organisms were a component of the root pruning symptom that we assessed each year. DNA profiles of potential pathogens during the final year indicated that species of Pythium clade F were present in amplified inoculum densities in most of the rotations. Species within clade F (25) that are pathogenic to small grains and are also known to be present in the Pacific Northwest include Pythium abappressorium, $P$. debaryanum, $P$. intermedium, $P$. paroecandrum, $P$. sylvaticum, and $P$. ultimum $(21,33,44)$. It was clear that seed treatments to protect seed and seedlings from one or more of these pathogens remains a critical need for agriculture in the Pacific Northwest, and that lengthy rotations and timely plantings will continue to be required for production of specialty products such as organic wheat or barley.

Root and lower stem diseases of food legume crops are common, chronic, and sometimes severe in the region of this study. However, food legume crops are planted on less than $1 \%$ of fields in the low-precipitation zone and, therefore, are not a subject of detailed research. Based upon previous research with lupin (Lupinus albus L.) at the experimental site (R. W. Smiley, unpublished data), stem lesions on the lower stem and upper root of peas in this experiment were considered to be caused by a pathogen complex including $F$. solani, $R$. solani AG-8, $R$. oryzae, Pythium spp., and $T$. basicola $(17,19)$. Of these suspected pathogens, the DNA analyses we used would have included inoculum levels only for $R$. solani AG-8 and Pythium spp. (32). Therefore, it was enlightening that the DNA analysis conducted by the Root Disease Testing Service (Adelaide, Australia) clearly implicated the involvement of Phoma medicaginis var. pinodella (37) as another component of the pathogen complex. This pathogen has been reported in higher precipitation regions of western Oregon and eastern Washington $(1,2)$ but, to the authors' knowledge, not from rainfed low-precipitation environments of north-central Oregon. The inoculum density was two times greater in plots currently planted to winter pea than in plots planted to winter wheat, suggesting an increasing level of inoculum production on the food legume crop host. Therefore, results of this study appear to extend the known range of $P$. medicaginis var. pinodella in the Pacific Northwest. This pathogen was also implicated in a succession of fungi associated with crown rot of alfalfa, which includes multiple species of Fusarium and Rhizoctonia (20).

In the rotation of winter wheat and winter pea, we detected an elevated density of $P$. thornei when winter pea was the current crop and an elevated density of Pratylenchus neglectus when winter wheat was the current crop (53). The density of Pratylenchus spp. was also greatest during 2008, the driest year of the experiment (53). The root pruning symptom was also very pronounced on all broadleaf species produced during that year; 65,53 , and $49 \%$ of plants for winter pea, spring pea, and camelina, respectively. The root pruning symptom was nil in all other years, suggesting the possibility that the symptom included involvement of Pratylenchus spp. as well as one or more fungal pathogens. Although root-lesion nematodes are unlikely to contribute directly to the occurrence of girdling stem lesions on winter pea, it is possible for them to become directly involved in the development of root lesions and root pruning. Additional studies of the pathogen complex associated with lesions on stems and roots of food legume crops in the semiarid Pacific Northwest are warranted.

Lesions on basal stems were detected on camelina but not on mustard. The suspected pathogens were $R$. solani and species of Pythium. The DNA analysis we used included the ability to detect inoculum concentrations for $R$. solani AG-8 and Pythium spp. (32). However, $R$. solani AG $2-1$ is also commonly associated with damping-off and root rot of brassicas (39), and this pathogen is present in semiarid regions similar to that for our experiment (30). We also reported that mustard but not camelina amplified the density of Pratylenchus sp. in this experiment (53). As stated previously, camelina roots had a high incidence (49\% of plants were symptomatic) of root pruning during 2008, a year in which mustard was not produced. That was the same year that the density of Pratylenchus spp. was greatest in this investigation. Further study of root and lower stem diseases of brassica crops will be warranted if the culture of these crops increases in response to current economic incentives for producing bioenergy crops.

Root and crown diseases of wheat have been studied intensively in the Pacific Northwest. Much is known about the species distribution and the importance of pathogens in the genera Bipolaris, Fusarium, Gaeumannomyces, Pratylenchus, Pythium, Rhizoctonia, and others $(36,48,55)$. The study reported here revealed many new findings that will provide additional guidance for research aimed at 
improving the efficiency of crop production in the Pacific Northwest. For instance, it was not previously reported that spring barley was more susceptible than spring wheat to Fusarium crown rot. This finding is worthy of additional scrutiny. The comparative uniformity of Pythium and Rhizoctonia inoculum levels among various tillage and cropping systems in areas of higher precipitation or irrigated agriculture was reported previously $(35,45)$ and, in this study, was confirmed under an even lower-precipitation environment. These findings have important implications regarding the development or refinement of farming practices that can be used to more effectively manage the disease process without necessarily attempting to reduce the inoculum density of these pathogens. Another important finding was that $P$. medicaginis var. pinodella was previously unsuspected as a component of the stem and root rot complex of food legume crops in the region. This will be important if cultivars with resistance to this pathogen can be identified and incorporated into rotational systems. Finally, potential associations between fungal pathogens and root-lesion nematodes must be considered in future research. Castillo and Vovlas (9) summarized the meager amount of information available regarding interactions of Pratylenchus spp. with pathogens such as $R$. solani and G. graminis var. tritici on cereal and food legume crops of importance in the Pacific Northwest. In this study, we examined multiple fungal pathogens and Pratylenchus spp. (53) but did not attempt to examine associations between these groups. Current research in Australia is revealing that, when fields are infested with both $P$. thornei and $F$. pseudograminearum, bread wheat cultivars having the least tolerance to the nematode express the greatest yield losses from the fungal pathogen even when environmental conditions are not particularly conducive to crown rot development (47). Comparable research on interactions of P. thornei and F. culmorum and of $H$. filipjevi, $F$. culmorum, and B. sorokiniana is being concluded in Iran. In that work, co-inoculation of rainfed winter wheat with $P$. thornei and $F$. culmorum caused additive suppressions of plant height, shoot weight, root weight, and grain yield (A. Hajihassani, personal communication). A greater understanding of interactions among these organisms could provide guidance for maximizing the yield efficiency of wheat cultivars in the Pacific Northwest.

\section{Acknowledgments}

This research was funded by an Oregon State University subcontract to the United States Department of Agriculture (USDA) Agricultural Research Service (SCA number 58-5348-9-100) and by a grant from the USDA Cooperative State Research Education and Extension Service Solutions to Economic and Ecological Problems (STEEP) Pacific Northwest Regional Research Program. We thank S. Easley, A. Thompson, J. Sheedy, and A. Spence for technical assistance; and S. Petrie and farmers who served on the advisory committee for this long-term experiment.

\section{Literature Cited}

1. Akamatsu, H. O., Chilvers, M. I., and Peever, T. L. 2008. First report of spring black spot and leaf spot of alfalfa in Washington State caused by Phoma medicaginis. Plant Dis. 92:833.

2. Anderson, A. J., and Powelson, M. L. 1979. Production of plant cell was degrading enzymes by Phoma medicaginis f. sp. pinodella. Phytopathology 69:372-375.

3. Bewick, L. S., Young, F. L., Alldredge, J. R., and Young, D. L. 2008. Agronomics and economics of no-till facultative wheat in the Pacific Northwest, USA. Crop Prot. 27:932-942.

4. Bithell, S. L., McKay, A., Butler, R. C., Herdina, Ophel-Keller, K., Hartley, D., and Cromey, M. G. 2012. Predicting take-all severity in second-year wheat using soil DNA concentrations of Gaeumannomyces graminis var. tritici determined with qPCR. Plant Dis. 96:443-451.

5. Bockus, W. W., Bowden, R. L., Hunger, R. M., Morrill, W. L., Murray, T. D., and Smiley, R. W., eds. 2010. Compendium of Wheat Diseases and Pests, 3rd ed. American Phytopathological Society, St. Paul, MN

6. Bowden, R. L., Wiese, M. V., Crock, J. E., and Auld, D. L. 1985. Root rot of chickpeas and lentils by Thielaviopsis basicola. Plant Dis. 69:1089-1091.

7. Bruehl, G. W. 1986. Soilborne Plant Pathogens. MacMillan Publishing Co., New York.

8. Burgess, L. W., Backhouse, D., Summerell, B. A., and Swan, L. J. 2001. Crown rot of wheat. Pages 271-294 in Fusarium-P. E. Nelson Memorial Symposium. B. A. Summerell, J. F. Leslie, D. Backhouse, W. L. Bryden, and L. W. Burgess, eds. American Phytopathological Society, St. Paul, MN.
9. Castillo, P., and Vovlas, N. 2007. Pratylenchus, Nematoda, Pratylenchidae: diagnosis, biology, pathogenicity and management. Nematol. Monogr. Perspect. 6:1-530.

10. Chamswarng, C., and Cook, R. J. 1985. Identification and comparative pathogenicity of Pythium species from wheat roots and wheat-field soils in the Pacific Northwest. Phytopathology 75:821-827.

11. Chen, W., Sharma, H. C., and Muehlbauer, F. J., eds. 2011. Compendium of Chickpea and Lentil Diseases and Pests. American Phytopathological Society, St. Paul, MN.

12. Cook, R. J. 1981. The effect of soil reaction and physical conditions. Pages 343-353 in. Biology and Control of Take-all. M. J. C. Asher and P. J. Shipton, eds. Academic Press, London.

13. Cook, R. J., 1981. Fusarium diseases of wheat and other small grains in North America. Pages 39-52 in: Fusarium: Diseases, Biology, and Taxonomy. P. E. Nelson, T. A. Toussoun, and R. J. Cook, R. J., eds. The Pennsylvania State University Press, University Park.

14. Cook, R. J., Schillinger, W. F., and Christensen, N. W. 2002. Rhizoctonia root rot and take-all of wheat in diverse direct-seed spring cropping systems. Can. J. Plant Pathol. 24:349-358.

15. Cook, R. J., Sitton, J. W., and Waldher, J. T. 1980. Evidence for Pythium as a pathogen of direct-drilled wheat in the Pacific Northwest. Plant Dis. 64:1061-1066.

16. Cook, R. J., and Veseth, R. J. 1991. Wheat Health Management. American Phytopathological Society, St. Paul, MN.

17. Corp, M., Machado, S., Ball, D., Smiley, R., Petrie, S., Siemens, M., and Guy, S. 2004. Chickpea production guide. Oregon State Univ. Ext. Publ. EM 8791-E.

18. Douglas, C. L., Jr., and Rickman, R. W. 1992. Estimating crop residue decomposition from air temperature, initial nitrogen content, and residue placement. Soil Sci. Soc. Am. J. 56:272-278.

19. Hampton, R. O., and Ford, R. E. 1965. Pea diseases in Washington and Oregon. Plant Dis. Rep. 49:235-238.

20. Hancock, J. G. 1996. Fungal and bacterial diseases of North American forage crops. Pages 165-186 in Pasture and Forage Crop Pathology. S. Chakraborty, K. L. Leath, R. A. Skipp, G. A. Pederson, R. A. Bray, G. C. M. Latch, and F. W. Nutter, Jr., eds. American Society of Agronomy, Madison, WI.

21. Higginbotham, R. W., Paulitz, T. C., and Kidwell, K. K. 2004. Virulence of Pythium species isolated from wheat fields in eastern Washington. Plant Dis. 88:1021-1026.

22. Ingram, D. M., and Cook, R. J. 1990. Pathogenicity of four Pythium species to wheat, barley, peas and lentils. Plant Pathol. 39:110-117.

23. Juergens, L. A., Young, D. L., Schillinger, W. R., and Hinman, H. R. 2004 Economics of alternative no-till spring crop rotations in Washington's wheat-fallow region. Agron. J. 96:154-158.

24. Kraft, J. M., and Pfleger, F. L., eds. 2001. Compendium of Pea Diseases and Pests, 2nd ed. American Phytopathological Society, St. Paul, MN.

25. Lévesque, C. A., and De Cock, W. A. M. 2004. Molecular phylogeny and taxonomy of the genus Pythium. Mycol. Res. 108:1363-1383.

26. Machado, S., Petrie, S., Rhinhart, K., and Qu, A. 2007. Long-term continuous cropping in the Pacific Northwest: tillage and fertilizer effects on winter wheat, spring wheat, and spring barley production. Soil Tillage Res. 94:473-481.

27. Mathre, D. E., ed. 1997. Compendium of Barley Diseases. American Phytopathological Society, St. Paul, MN.

28. Mazzola, M., Smiley, R. W., Rovira, A. D., and Cook, R. J. 1996. Characterization of Rhizoctonia isolates, disease occurrence and management in cereals. Pages 249-258 in Rhizoctonia Species: Taxonomy, Molecular Biology, Ecology, Pathology and Disease Control. B. Sneh, S. Jabaji-Hare, S. Neate, and G. Dijst, eds. Kluwer Academic Publishers, Dordrecht, The Netherlands.

29. Moore, K. J., and Cook, R. J. 1984. Increased take-all of wheat with directdrilling in the Pacific Northwest. Phytopathology 74:1044-1049.

30. Okubara, P. A., Schroeder, K. L., and Paulitz, T. C. 2008. Identification and quantification of Rhizoctonia solani and $R$. oryzae using real-time polymerase chain reaction. Phytopathology 98:837-847.

31. Ogoshi, A., Cook, R. J., and Bassett, E. N. 1990. Rhizoctonia species and anastomosis groups causing root rot of wheat and barley in the Pacific Northwest. Phytopathology 80:784-788

32. Ophel-Keller, K., Hartley, D., McKay, A., Herdina, and Curran, J. 2008. Development of a routine DNA-based testing service for soilborne diseases in Australia. Australas. Plant Pathol. 37:243-253.

33. Paulitz, T. C., and Adams, K. 2003. Composition and distribution of Pythium communities in wheat fields in eastern Washington State. Phytopathology 93:867-873.

34. Paulitz, T. C., and Schroeder, K. L. 2005. A new method for the quantification of Rhizoctonia solani and R. oryzae from soil. Plant Dis. 89.767-772.

35. Paulitz, T. C., Schroeder, K. L., and Schillinger, W. F. 2010. Soilborne pathogens of cereals in an irrigated cropping system: effects of tillage, residue management, and crop rotation. Plant Dis. 94:61-68.

36. Paulitz, T. C., Smiley, R. W., and Cook, R. J. 2002. Insights into the prevalence and management of soilborne cereal pathogens under direct seeding in the Pacific Northwest, U.S.A. Can. J. Plant Pathol. 24:416-428.

37. Punithalingam, E., and Gibson, I. A. S. 1976. Phoma medicaginis var. 
pinodella. CMI Descriptions of Pathogenic Fungi and Bacteria, No. 518, Commonw. Mycol. Inst. Kew, Surrey, England.

38. Ramsey, N. E. 2001. Occurrence of take-all on wheat in Pacific Northwest cropping systems. M. S. thesis, Washington State University, Pullman.

39. Rimmer, S. R., Shattuck, V. I., and Buchwaldt, L., eds. 2007. Compendium of Brassica Diseases. American Phytopathological Society, St. Paul, MN.

40. Schillinger, W. F., Cook, R. J., and Papendick, R. I. 1999. Increased dryland cropping intensity with no-till barley. Agron. J. 91:744-752.

41. Schillinger, W. F., Kennedy, A. C., and Young, D. L. 2007. Eight years of annual no-till cropping in Washington's winter wheat-summer fallow region. Agric. Ecosyst. Environ. 120:345-358.

42. Schillinger, W. F., Papendick, R. I., Guy. S. O., Rasmussen, P. E., and Van Kessel, C. 2006. Dryland cropping in the western United States. Pages 365393 in: Dryland Agriculture, 2nd ed. G. A. Peterson, P. W. Unger, and W. A. Payne, eds. Agron. Monogr. 23. American Society of Agronomy, Madison, WI.

43. Schillinger, W. F., and Young, D. L. 2004. Cropping systems research in the world's driest rainfed wheat region. Agron. J. 96:1182-1187.

44. Schroeder, K. L., Okubara, P. A., Tambong, J. T., Lévesque, C. A., and Paulitz, T. A. 2006. Identification and quantification of pathogenic Pythium spp. from soils in eastern Washington using real-time polymerase chain reaction. Phytopathology 96:637-647.

45. Schroeder, K. L., and Paulitz, T. C. 2006. Root diseases of wheat and barley during the transition from conventional tillage to direct seeding. Plant Dis. 90:1247-1253.

46. Schuster, M. L. 1948. The etiology and control of root and stem rots of peas in Washington. Wash. Agric. Exp. Stn. Bull. No. 499, Pullman.

47. Simpfendorfer, S., McMullen, G., and Brill, R. 2012. Interaction of crown rot with root-lesion nematodes. Page 34 in: Proc. 1st Int. Crown Rot Workshop Wheat Improve. R. I. S. Brettell and J. M. Nicol, eds. CIMMYT, El Batan, Mexico.

48. Smiley, R. W. 2009. Water and temperature parameters associated with winter wheat diseases caused by soilborne pathogens. Plant Dis. 93:73-80.

49. Smiley, R. W., Backhouse, D., Lucas, P., and Paulitz, T. E. 2009. Diseases which challenge global wheat production-root, crown, and culm rots. Pages 125-153 in: Wheat Science and Trade. B. F. Carver, ed. Wiley-Blackwell, Ames, IA.
50. Smiley, R. W., Collins, H. P., and Rasmussen, P. E. 1996. Diseases of whea in long-term agronomic experiments at Pendleton, Oregon. Plant Dis. 80:813-820.

51. Smiley, R. W., Gourlie, J. A., Easley, S. A., Patterson, L.-M., and Whittaker, R. G. 2005. Crop damage estimates for crown rot of wheat and barley in the Pacific Northwest. Plant Dis. 89:595-604.

52. Smiley, R. W., and Machado, S. 2009. Pratylenchus neglectus reduces yield of winter wheat in dryland cropping systems. Plant Dis. 93:263-271.

53. Smiley, R. W., Machado, S., Gourlie, J. A., Pritchett, L. C., Yan, G. P., and Jacobsen, E. E. 2013. Effects of crop rotations and tillage on Pratylenchus spp. in the semiarid Pacific Northwest United States. Plant Dis. 97:537-546.

54. Smiley, R. W., Merrifield, K., Patterson, L.-M., Whittaker, R. G., Gourlie, J. A., and Easley, S. A.. 2004. Nematodes in dryland field crops in the semiarid Pacific Northwest USA. J. Nematol. 36:54-68.

55. Smiley, R. W., and Nicol, J. M. 2009. Nematodes which challenge globa wheat production. Pages 171-187 in: Wheat Science and Trade. B. F. Carver, ed. Wiley-Blackwell, Ames, IA.

56. Smiley, R. W., and Patterson, L.-M. 1996. Pathogenic fungi associated with Fusarium foot rot of winter wheat in the semiarid Pacific Northwest. Plan Dis. 80:944-949.

57. Smiley, R. W., Patterson, L.-M., and Shelton, C. W. 1996. Fungicide seed treatments influence emergence of winter wheat in cold soil. J. Prod. Agric. 9:559-563.

58. Smiley, R. W., Ogg, A. G., Jr., and Cook, R. J. 1992. Influence of glyphosate on Rhizoctonia root rot, growth, and yield of barley. Plant Dis. 76:937 942.

59. Smiley, R. W., and Uddin, W. 1993. Influence of soil temperature on Rhizoctonia root rot ( $R$. solani AG-8 and $R$. oryzae) of winter wheat. Phytopathology 83:777-785.

60. Smiley, R. W., and Wilkins, D. E. 1993. Annual spring barley growth, yield, and root rot in high- and low-residue tillage systems. J. Prod. Agric. 6:270275

61. Smiley, R. W., Wilkins, D. E., and Case, S. E. 1991. Barley yields as related to use of seed treatments in eastern Oregon. J. Prod. Agric. 4:400-407.

62. Zerlik, G. M. 1979. A late yellowing and foot rot of peas. Pages 337-342 in: Soil-Borne Plant Pathogens. B. Schippers and W. Gams, W., eds. Academic Press, London. 